\title{
Growth and Instability in Export of Tobacco from India
}

\author{
Bharati R. Bagari* and Jayashree A. Handigol \\ Department of Agricultural Economics, College of Agriculture, UAS, Dharwad-580005, \\ Karnataka, India \\ *Corresponding author
}

\section{Keywords \\ CAGR, Instability index, Positive growth rate, Significance \\ Article Info \\ Accepted: \\ 20 June 2019 \\ Available Online: \\ 10 July 2019}

\section{A B S T R A C T}

Tobacco industry in India is one of the largest in the world with India having the largest area under tobacco cultivation. It plays an important role in the country's economy. Compound annual growth rate and Cuddy-DelleVelle instability index were used to measure the growth and instability in export of tobacco from India. The necessary secondary data were collected for a period of 22 years from 1994-95 to 2015-16. There is a positive and significant growth rate in export of tobacco both in terms of quantity $(6.20 \%)$ and value (14.25\%) which was associated with a medium instability index. This shows that the share of Indian tobacco compared to the global share of tobacco traded was found to be favourable and hence the advantageous situation could be for India. Therefore there is need to regulate and explore new technologies and market for better exploitation of tobacco at large to boost Indian exports.

\section{Introduction}

Tobacco (Nicotiana tobaccum) is an important commercial crop, which plays a significant role in Indian economy. Tobacco is also called as 'Golden leaf', it is an agro based product processed from leaves. India earned the distinction of being the world's second largest producer of tobacco, next only to China.

Tobacco was introduced into India by Portuguese traders during 1600 AD. Its use and production proliferated to such a great extent that today India is the third leading exporter of tobacco with an around 9.4 percent share in the world total exports of tobacco. Tobacco is a traditional agricultural export commodity. In India, major tobacco growing states are Andhra Pradesh, Karnataka, Gujarat Tamil Nadu, Maharashtra, Uttar Pradesh and Bihar. Among these Andhra Pradesh is the leading state followed by Gujarat and Karnataka states. Presently India stands second position in export of tobacco and its products. Tobacco is exported to more than 80 countries over the world. India has a large, highly integrated tobacco industry, involving the growing of a range of leaf types, the 
manufacture of different tobacco products, including unprocessed and chewing tobacco, and an extensive distribution and retail system.

\section{Materials and Methods}

The data used for the study is entirely based on Secondary source. For this study twenty two years data were collected i.e., from 199495 to 2015-16. The year wise data on export of tobacco in terms of quantity and value is compiled from various sources like Tobacco Board, Guntur, Food and agricultural organisation (FAO), and Indiastat.

\section{Compound growth rate analysis}

For evaluating the growth rate in export of tobacco from India, compound growth rates were computed using the following form of the relationship.

$Y_{t}=a b^{t} U_{t} \ldots(1)$

Where,

$Y_{t}=$ Dependent variable for which growth rate was estimated (quantity and value of tobacco exported in year ' $t$ ').

$\mathrm{a}=$ Intercept

$\mathrm{b}=$ Regression coefficient

$\mathrm{t}=$ Year which takes values $1,2, \ldots \mathrm{n}$.

$\mathrm{U}_{\mathrm{t}}=$ Disturbance term in year ' $\mathrm{t}$ '.

The equation (1) was transformed into loglinear and written as

$\log \mathrm{Y}_{\mathrm{t}}=\log \mathrm{a}+\mathrm{t} \log \mathrm{b}+\log \mathrm{U}_{\mathrm{t}} \ldots$ (2)

Equation (2) was estimated by using Ordinary Least Square (OLS) technique.

The compound growth rate $(\mathrm{g})$ was then estimated by the identity given in equation (3) $g=(b-1) \times 100 \ldots(3)$

Where,

$\mathrm{g}=$ Estimated compound growth rate per annum in percentage.

$b=$ Antilog of $\log b$

\section{Instability index by Cuddy and Della}

In order to examine the extent of variability in export of tobacco, Cuddy-Della-Velle index was worked out

Instability Index $=(\mathrm{SD} / \mathrm{mean}) \times 100 \times \sqrt{ }\left(1-\mathrm{r}^{2}\right)$

Where,

$\mathrm{SD}=$ standard deviation

Mean $=$ mean of export of tobacco

$\mathrm{r}^{2}=\mathrm{RSS} / \mathrm{TSS}=$ Goodness of fit

RSS = Regression Sum of Square

TSS $=$ Total Sum of Square

\section{Results and Discussion}

The exports of tobacco both in terms of quantity and value was analysed using exponential growth model and instability index (Cuddy and Della method). Table 1 shows the export of tobacco from India since twenty two years from 1994-95 to 2015-16 both in terms of quantity and value. The table depicts that during 1994-95 the export of tobacco in terms of quantity was 55,422 tones which had been increased to $2,43,418$ tones during 2015-16 with an increasing growth rate of 6.20 per cent per annum and was associated with an instability index of 15.48 per cent. Similarly the export of tobacco in terms of value during 1994-95 was 267.78 crores which had been increased to 6,058.13 crores with an increasing growth rate of 14.25 per cent per annum and was associated with an instability index of 21.65 per cent. 
Growth rate for export of tobacco in terms of quantity was positive (6.20\%), and was associated with an instability index of 15.48 per cent. While a positive growth rate of tobacco exports in terms of value $(14.25 \%)$ with an instability index of 21.62 per cent was observed during the study period. The result showed positive and significant growth in exports of tobacco both in terms of quantity and value during 1994-95 to 2015-16. Increase in the exports of tobacco is due to increase in the demand for Indian tobacco products in foreign countries especially in Belgium and UAE. Similar findings were found by Patil and Smita (2006), who studied the trends in export of grapes from India. The compound growth rate for quantity of grapes exported was 12.05 per cent per annum. With respect to value obtained from export of grapes, the corresponding compound growth rate indicated an increase of 22 per cent per annum.

Table.1 Export of tobacco from India

\begin{tabular}{|c|c|c|}
\hline Year & Quantity (ton) & Value (Rs. Crs.) \\
\hline 1994-95 & 55,422 & 267.78 \\
\hline $1995-96$ & 83,935 & 421.04 \\
\hline 1996-97 & $1,30,581$ & 826.52 \\
\hline $1997-98$ & $1,44,534$ & $1,061.19$ \\
\hline 1998-99 & $1,01,323$ & 806.19 \\
\hline 1999-20 & $1,36,221$ & $1,050.22$ \\
\hline 2000-01 & $1,15,930$ & 903.38 \\
\hline 2001-02 & $1,02,086$ & 888.52 \\
\hline 2002-03 & $1,27,557$ & $1,095.95$ \\
\hline 2003-04 & $1,50,962$ & $1,175.63$ \\
\hline 2004-05 & $1,62,933$ & $1,362.18$ \\
\hline 2005-06 & $1,66,869$ & $1,413.47$ \\
\hline 2006-07 & $1,80,988$ & $1,723.42$ \\
\hline 2007-08 & $2,05,347$ & $2,022.78$ \\
\hline 2008-09 & $2,24,867$ & $3,388.43$ \\
\hline 2009-10 & $2,59,566$ & $4,402.29$ \\
\hline 2010-11 & $2,52,298$ & $4,210.41$ \\
\hline 2011-12 & $2,40,395$ & $4,100.30$ \\
\hline 2012-13 & $2,63,575$ & $4,879.05$ \\
\hline 2013-14 & $2,66,038$ & $6,092.86$ \\
\hline 2014-15 & $2,49,150$ & $5,652.17$ \\
\hline 2015-16 & $2,43,418$ & $6,058.13$ \\
\hline CAGR (\%) & $6.20 * *$ & $14.25 * *$ \\
\hline $\begin{array}{c}\text { INSTABILITY } \\
\text { INDEX }(\%)\end{array}$ & 15.48 & 21.65 \\
\hline
\end{tabular}

Note: ** indicates the results are highly significant. 
In India the export of tobacco is characterised by stable growth both in terms of quantity and value throughout the period of 22 years. This shows that the share of Indian tobacco compared to the global share of tobacco traded was found to be favourable and hence the advantageous situation could be for India. Therefore there is need to regulate and explore new technologies and market for better exploitation of tobacco at large to boost Indian exports.

\section{References}

Ashoka, N., Kuldeep, C., Ramach Andhra, V. A. and Yeledhalli, R. A., 2011. A study on growth, instability and direction of chilli trade in India. J. Spices and Aromatic Crops, 22 (1): 76-80.
Ganapathy, Manohara, M. R, Mahadeva Murthy, M., and Rjashekaramurthy, S., 2014. The degree of instability in export of Indian silk product. Int. J. Business and General Mngt., 3 (3): 135-138.

Patil, M. T. and Smita, S., 2008. Trends in exports of grapes from India. Indian $J$. Agric. Mktg., 50 (4): 5-11.

Thanuja, W. J., 2006. Export performance and competitiveness of ginger from India. M. Sc. (Agri.) Thesis, Univ. Agric. Sci., Dharwad, Karnataka (India).

Vilas, K. and Yeledalli, R. A., 2009. Direction of trade and export competitiveness of onion. Agric. Updates, 4 (3): 237-243.

www.faostat.com

www.indiastat.com

\section{How to cite this article:}

Bharati R. Bagari and Jayashree A. Handigol. 2019. Growth and Instability in Export of Tobacco from India. Int.J.Curr.Microbiol.App.Sci. 8(07): 2507-2510. doi: https://doi.org/10.20546/ijcmas.2019.807.309 